------ Raf. J. Sci., Vol. 23, No.1 pp 116-125, 2012------

\title{
The Optical and Electrical Properties of CdSe Thin Films Prepared by CBD Technique
}

\author{
Nawfal Y. Jamil
}

\author{
Marwa T. Mahmood \\ Department of Physics \\ Collage of Science \\ University of Mosul
}

\author{
Noor A. Mustafa
}

(Received 28/2/2011;Accepted 26/9/2011)

\begin{abstract}
In this work thin films of CdSe were deposited on glass substrate by chemical bath deposition technique at different deposition temperatures 298,318 , and $328 \mathrm{~K}$. The effects of deposition temperature on the optical properties have been studied as well as the effect of annealing at different temperatures $(373,473,573$ and $673 \mathrm{~K})$ for one hour. The optical properties of CdSe were studied from transmittance measurements as a function of a range of wave lengths (320-1000 nm). Optical band gap has been decreased from 2 to $1.7 \mathrm{eV}$ after annealing. CdSe/p-Si was prepared by depositing CdSe film on the p-type Si substrate. The I$\mathrm{V}$ characteristics showed a diode behavior.
\end{abstract}

Keywords: CdSe, Optical Properties, Thin Films, CBD technique.

الخواص البصربة والكهربئية لأغشية CdSe المحضرة جلرقة ترسيب الحملم الكيميأي

\section{(CBD)}

\section{المالخص}

في هذا البمث مت تحضير أغثية CdSe بطريقة ترسيب الحملم الكيميائي (CBD) عند درجلت حرارة مختلفة (298, 318 and 328 K)، ودرلسة تأثير درجلت حرارة الترسيب على الخواص البصرية وتأثير التلدين

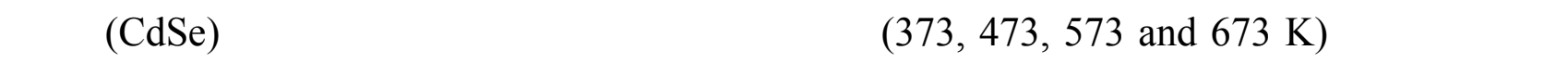
قيلس الفانية بوصفها دالة لاطول الموجي ضنم المدى (320-1000 nm ووجد أن طاقة الفجوة البصرية نقل من 2 إلى 1.7 الكترون - فولت بعد التلدين. قم تحضير CdSe/p-Si بترسيب غنشاء CdSe على نماذج من

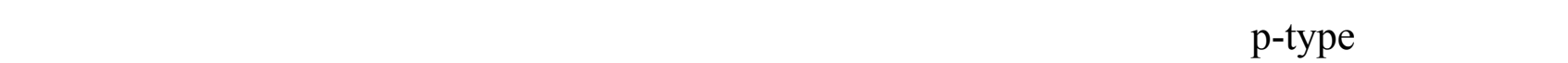
قيلسلت I-V

الكاملت الدالة : لمdSe، الخواص البصرية، الأغثية الرقيقة، ققنية CBD. 


\section{INTRODUCTION}

In recent year major attention is being showed in II-VI Semiconductor compounds because of their specific optoelectronic properties, such as high efficiency of radioactive recombination, high absorption coefficient in the visible and infrared regions of the solar spectrum (Patel et al., 2009), (Sharma et al., 2008), good electrical properties, increased capability in obtaining adjustable n-type or p-type conductivity by doping and direct band-gap (Perez and Arrealas, 2009).

Cadmium Selenide is one of the well known of this group binary compounds as important material because of its containing active regions which can be used to produce light emission. The spectral range $(460-530) \mathrm{nm}$ and suitable band gap $(1.74 \mathrm{eV})$ (Tamargo ; 2002), can be used for optoelectronic devices such as solar cells (Masumdar and Deshumkh; 2003), (PEC)cells (Gudage et al., 2007) and light emitting diodes ..etc.

CdSe thin films have been prepared by various film deposition techniques such as sputtering (Moersch et al., 1989), MOCVD (Chae et al., 2006), electron beam evaporation (Murali et al., 2008), photoelectrochemical (Pawar et al., 2006), and chemical bath deposition (CBD) method which is found to be cheap, low deposition temperature and simple way to deposit large area thin film (Kale and Lokhande;2005), (Ezema and Osuji, 2007) and (Elahi and Ghobad, 2008).

In present paper the effect of the preparation conditions on the optical properties of CdSe thin films is investigated. Also a p-n junction had been studied.

\section{EXPERIMENTAL}

Cadmium selenide thin films were deposited on glass substrate by using chemical bath deposition (CBD) technique.

Selenium is not soluble in water in order to create selenium ions. Selenium powder were mixed with solution of sodium sulphite and the solution under reflex condition has been heated for a period between 1-2 hours (Eya, 2006).

$$
\begin{aligned}
\mathrm{Se}+\mathrm{Na}_{2} \mathrm{SO}_{3} \stackrel{\text { reflex }}{\rightarrow} \mathrm{Na}_{2} \mathrm{SeSO}_{3} & \rightarrow \\
& \downarrow \\
& \mathrm{Se}^{-2}
\end{aligned}
$$

$\left(\mathrm{Na}_{2} \mathrm{SeSO}_{3}\right)$ mixed with $\left(\mathrm{CdCl}_{2}\right)$ and added $\left(\mathrm{NH}_{3}\right)$ was used as complex agent in the beaker, after mixing the $\mathrm{pH}$ of the solution become $\sim 11 \pm 1$, which is measured by using $\mathrm{pH}$ paper which agree with (kale and lokande, 2004).

$2 \mathrm{CdCl}_{2}+4 \mathrm{NH}_{3} \leftrightarrow\left[\mathrm{Cd}\left(\mathrm{NH}_{3}\right)_{4}\right]^{+2}+\mathrm{CdCl}_{4}$

$\left[\mathrm{Cd}\left(\mathrm{NH}_{3}\right)_{4}\right]^{+2} \leftrightarrow \mathrm{Cd}^{+2}+4 \mathrm{NH}_{3}$

$\mathrm{Na}_{2} \mathrm{SeSO}_{3}+2 \mathrm{OH}^{-} \leftrightarrow \mathrm{Na}_{2} \mathrm{SO}_{4}+\mathrm{H}_{2} \mathrm{O}+\mathrm{Se}^{-2}$

$\mathrm{Cd}^{+2}+\mathrm{Se}^{-2} \leftrightarrow \mathrm{CdSe} \downarrow$ 
Substrate cleaning plays an important role in the deposition of thin films. Glass microscope slides cleaned by soap solution and heated in boiled alcohol finally washed by dionized water before use. The glass substrate inclined vertically at $20^{\circ}$ angle to the walls of beaker immersed in the solution for a deposition time between (24-72 h). The CdSe thin films were uniform well adherent to the substrates and red-orange in color. CdSe also deposited at different temperatures 298,318 and $328 \mathrm{~K}$ to study the effect of the deposition temperatures on the optical properties of the films. The prepared samples were annealed at 373, 473, 573 and $673 \mathrm{~K}$ for one hour in order to study the effect of annealing on the optical properties and of prepared CdSe samples. The spectrum was measured by a spectrophotometer model 721-2000.

The thickness of the films were measured by using the equation:

$$
t=\frac{m}{A \rho}
$$

$t$ is the film thickness, $m$ is the mass of deposited CdSe, $\rho$ is density of the CdSe $=5.816$ $\mathrm{g} / \mathrm{cm}^{3}$ and $A$ is the area of sample.

$\mathrm{CdSe}$ was deposited by (CBD) on a p-Si substrate. From the I-V Measurements we obtained a diode characteristics and study the mechanism of carrier transport.

\section{Optical properties}

\section{RESULT AND DISUSSION}

\section{Effect of deposition temperatures:}

CdSe thin films were prepared by chemical path deposition at different deposition temperatures 298, 318 and $328 \mathrm{~K}$. Fig. 1 shows transmittance spectra, which revealed the films have high transmittance in the near infrared region $(700-990 \mathrm{~nm})$ and in the visible region $(390-770 \mathrm{~nm})$ but the transmittance decreases in the ultraviolet region $(350-400 \mathrm{~nm})$ of the electromagnetic spectrum. Fig. 2 shows the optical absorbance spectra. 


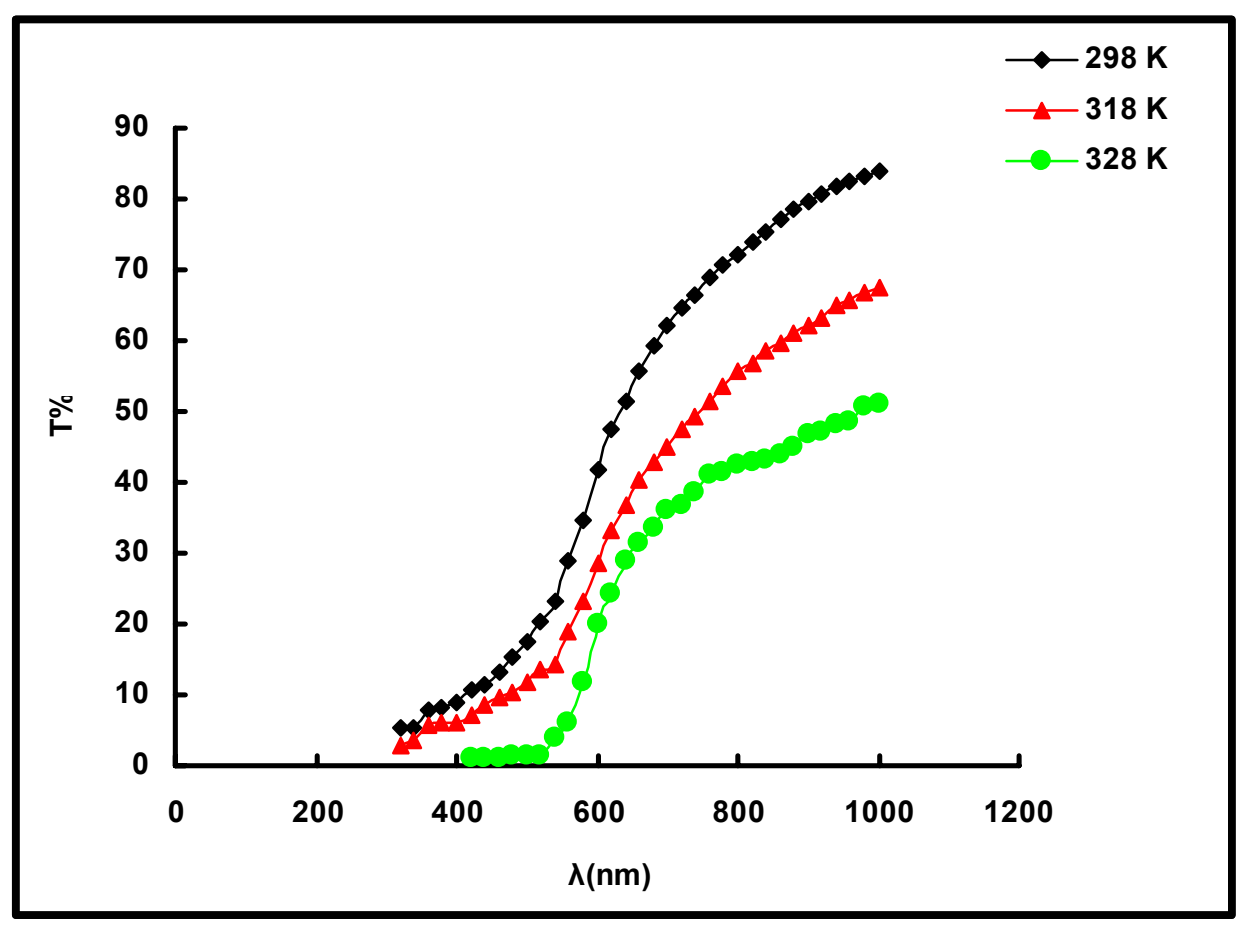

Fig. 1: Transmittance spectra of CdSe thin films deposited at different temperatures.

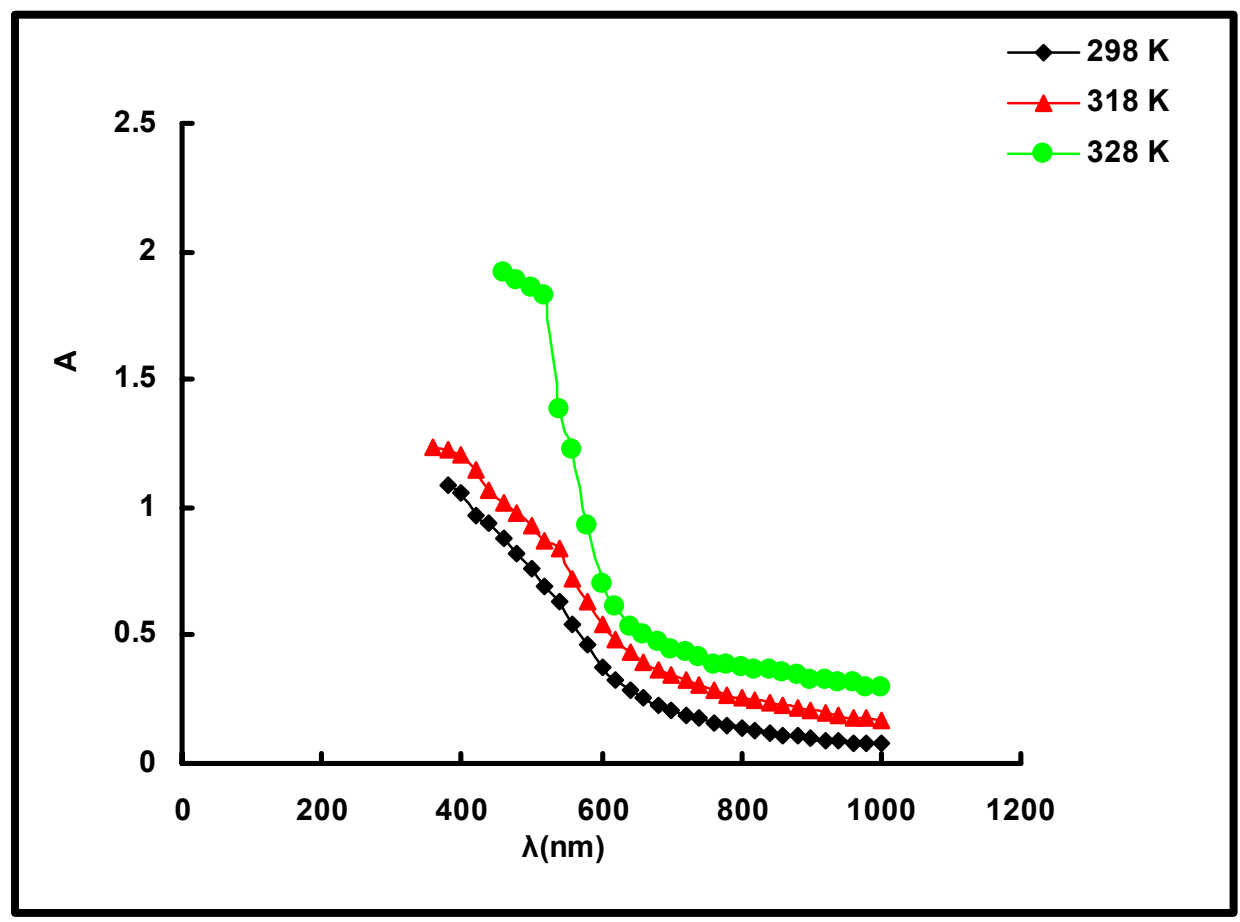

Fig. 2: Absorbance spectra of CdSe thin films deposited at different temperatures. 


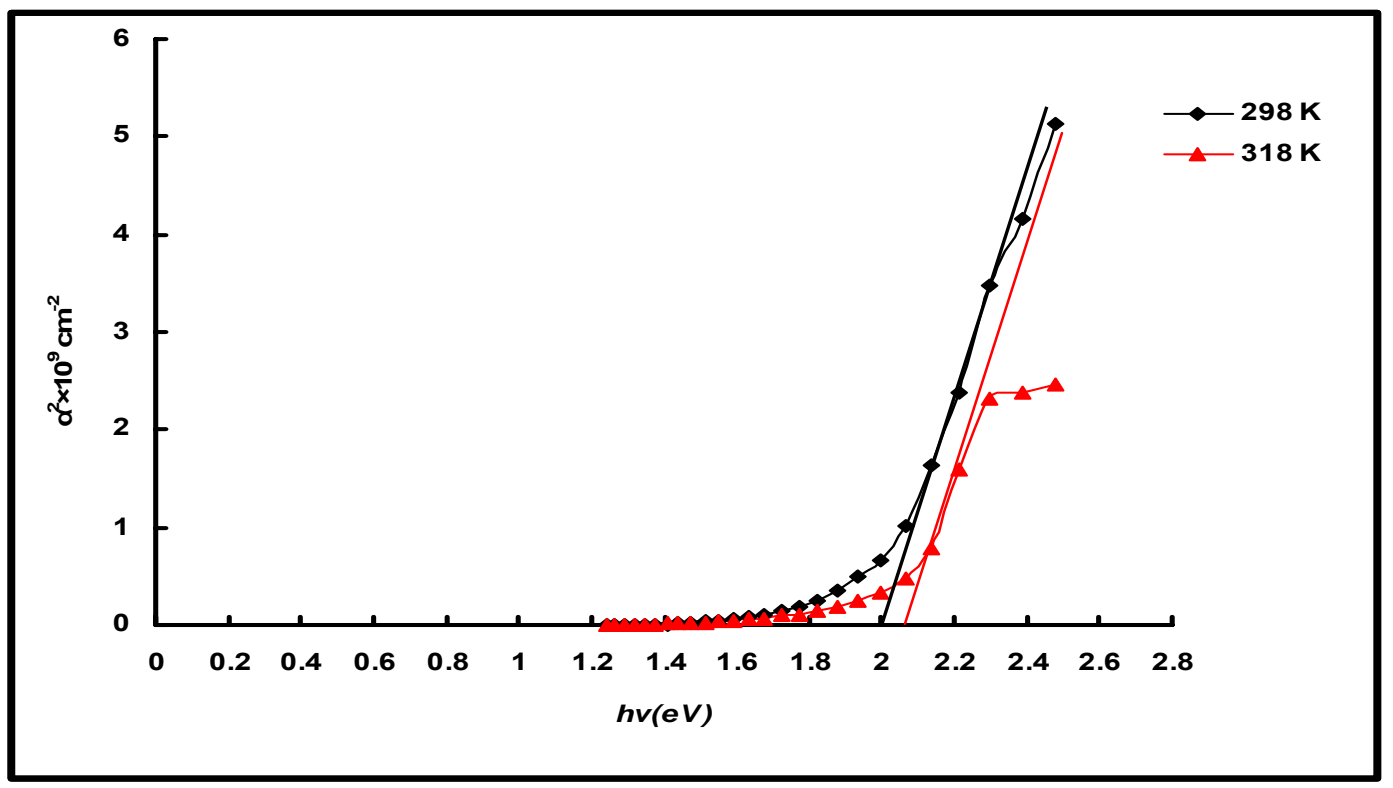

(a)

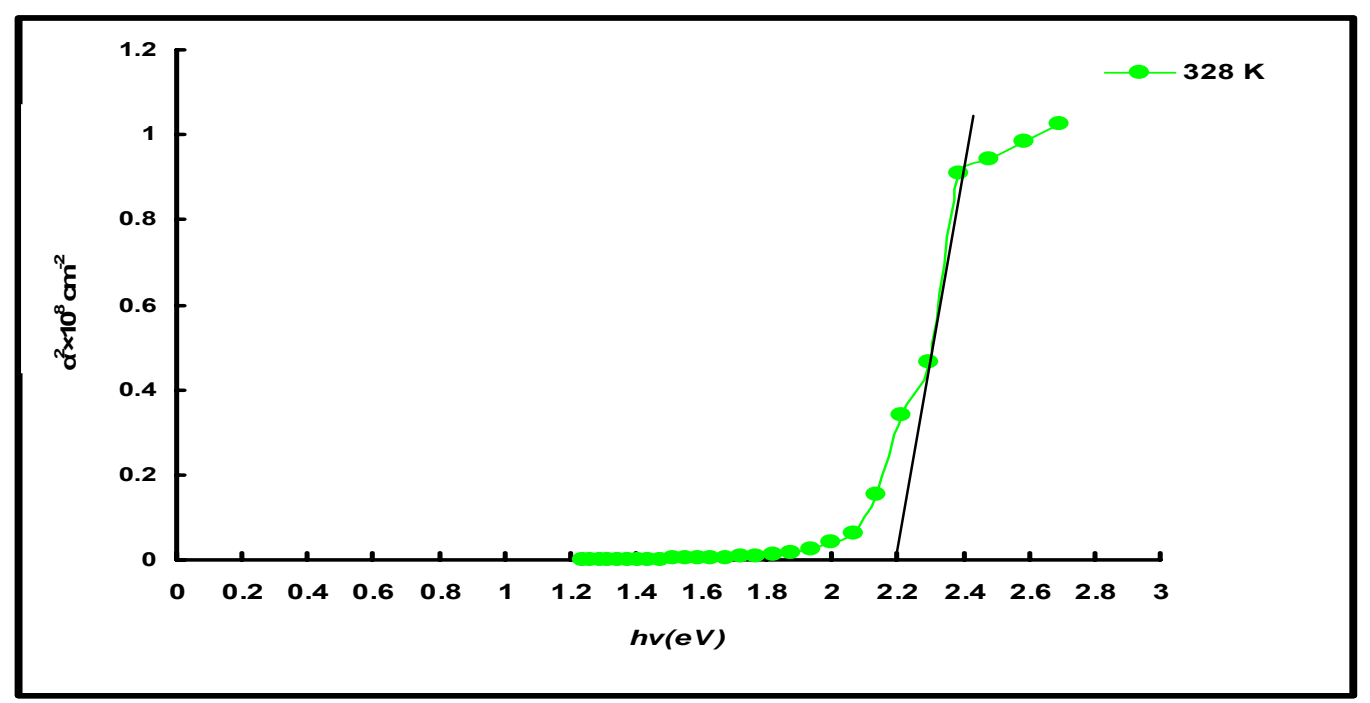

(b)

Fig. 3:(a,b) $\left(\alpha^{2}\right)$ ver sus(E) for CdSe thin films at different deposition temperature

Fig.3 shows the relation between the absorption coefficient and the incident photon energy and the extra polation of the linear portion yield a direct band gap (Khoman and Hankare, 2009).

The fundamental absorption which corresponding to the transition from valence to conduction band, by employment on the fig.1 and using the equation (Silverstein and Bassler, 1963): 


$$
\mathrm{A}=\log (1 / \mathrm{T})
$$

Where $A$ is absorbance and $\mathrm{T}$ is a transmittance can be calculate the absorbance of the films. The band gap of the material can be determined by using the relation between absorption coefficient $(\alpha)$ and the incident photon energy $(h v)$ as in (Pankove, 1971).

$$
\alpha=\beta(h v-E g)^{n} / h v
$$

Where $\beta$ is a constant and the exponent (n) depends on the type of transition have many values $(1 / 2,2,3 / 2$ and 3$)$ corresponding to allowed direct, allowed in direct, forbidden direct and forbidden indirect transition, respectively.

Further absorption coefficient $(\alpha)$ can be simplified as (Abbas and Mohamed, 1986)

$$
\alpha=2.303\left(A-A^{\prime}\right) / t
$$

Where $A$ is absorbance, $A^{\prime}$ is reflectance, $t$ is thickness of the films which is $(0.23,0.4,3.7$ $\mu \mathrm{m})$ at different deposition temperatures $(298,318,328 \mathrm{~K})$ respectively, Fig. (3).

The values of band gap ( $E g)$ determined from the plots of $\left(\alpha^{2}\right)$ versus $(h v)$ are shown in The linear nature of plot indicates the existence of the direct transition. The optical band gap of CdSe films were found to be in the range $(2-2.2 \mathrm{eV})$ which agrees with earlier investigators repot (Kale and Lokhande, 2004), (Eya, 2006) and (Gudage et al., 2009).

Fig. 3 shows that as the deposition temperature increases the band gap of prepared films increases as well (Sharma et al., 2008), this is could be expect due to increase in the deposition rate and decreasing in grain size and probability deposited impurity materials or defects. The thickness of the films is proportional to the temperature of deposition as shown in Fig. 4.

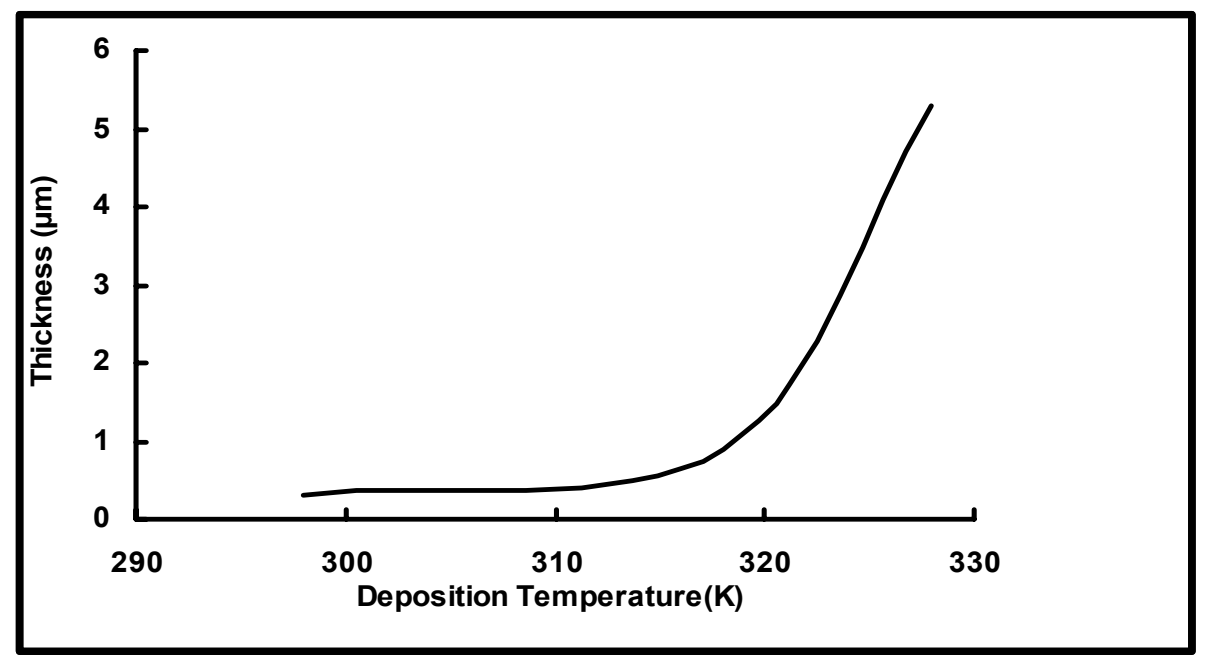

Fig. 4: Thickness of the films versus deposition temperatures.

\section{Effect of annealing temperature on the optical properties}

The films show an increase in optical absorption after annealing at $(373,473,573$ and $673 \mathrm{~K}$ ) for one hour the films exhibits strong red shift in their optical spectra. The increase of annealing temperature caused gradually decrease of the band gap from 2 to $1.7 \mathrm{eV}$ Fig.5 this possibility is due to the increase in grain size. The increase in grain size films decrease the 
grain boundaries, and the change in color from red-orange to dark-brown which is in agreement with the reported value by others (Kale and Lokhande, 2004).
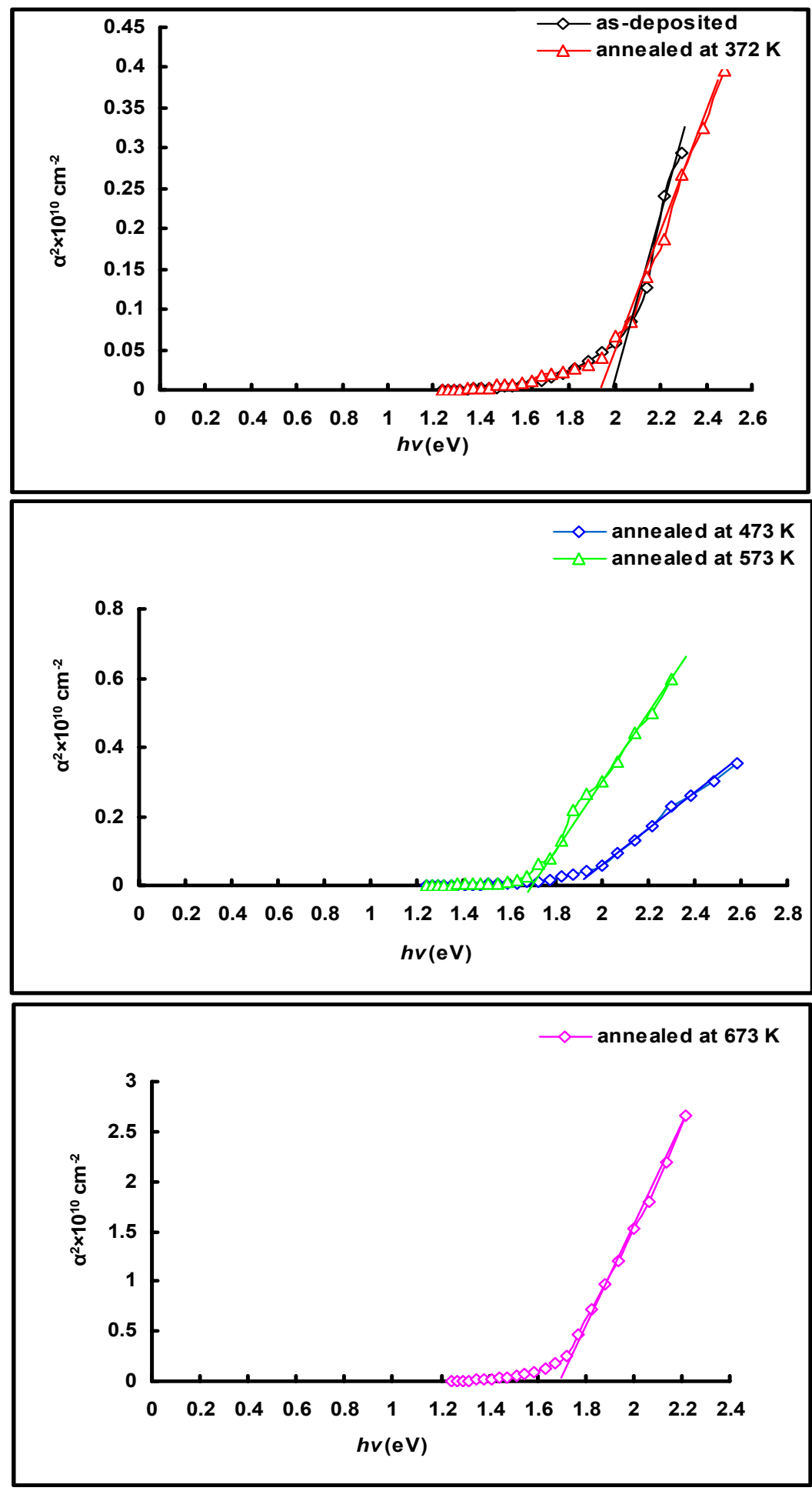

Fig. 5: $\left(\alpha^{2}\right)$ versus $(h v)$ for CdSe thin films deposited at room temperature and annealing at different temperatures. 


\section{Electrical properties}

\section{Current-voltage characteristics:}

The CdSe film deposited on the silicon substrate as described before to prepare $\mathrm{CdSe} / \mathrm{Si}$ device and from I-V measurements. It is observed that $\mathrm{CdSe} / \mathrm{p}-\mathrm{Si}$ show a diode behavior as shown in Fig.6. The increase in forward current can be expected due to the decrease in the barrier height.

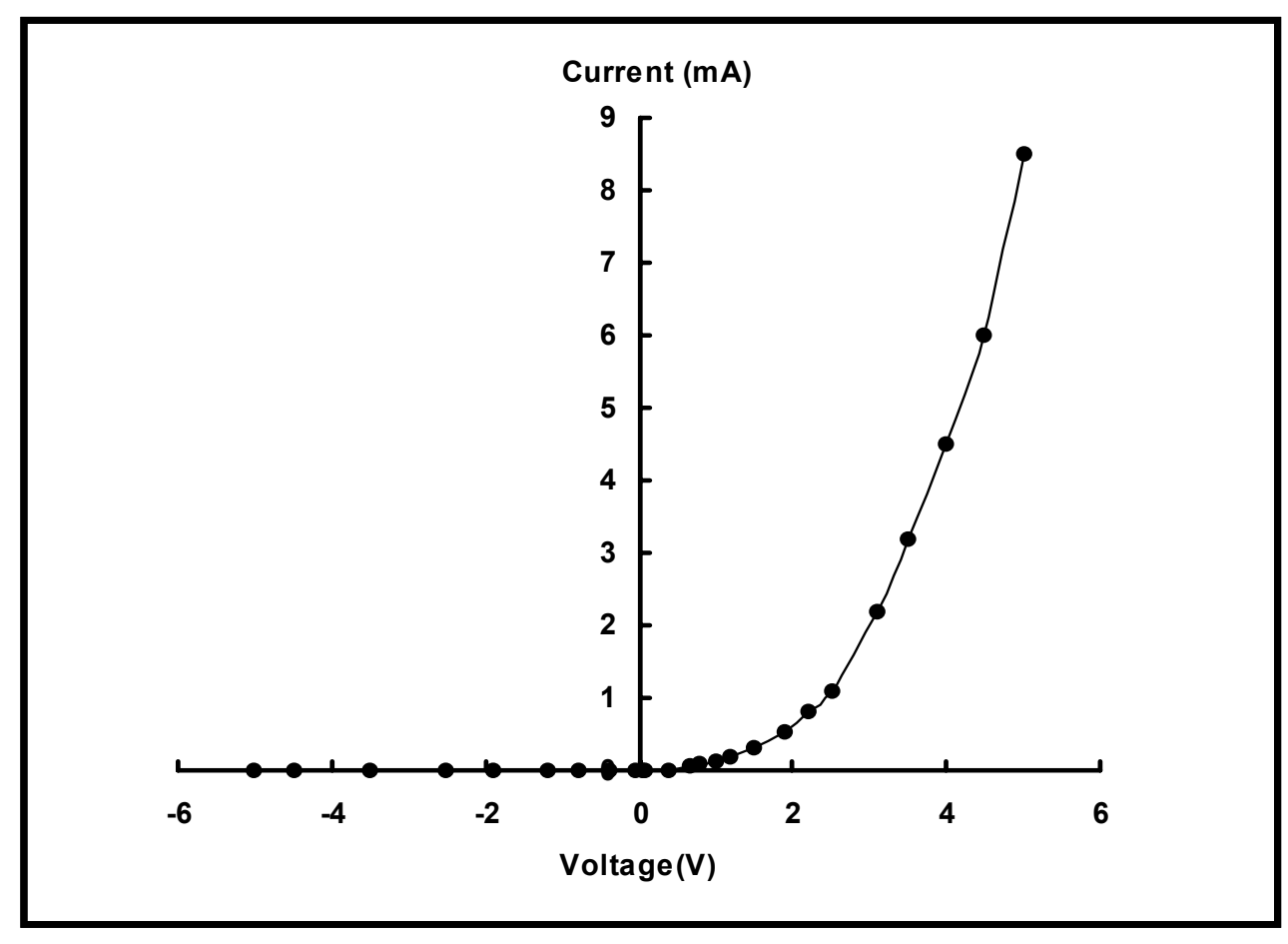

Fig. 6: Current-voltage characteristics of CdSe film.

The logarithm relation between I and V, as shown in Fig.7, appear that a linear relation was obtained and this give an idea that the mechanism of conductivity is by space charge limited current since the value of $m$ in the relation $I \alpha V^{m}$ is equal 2. (Lade et al., 2001) 


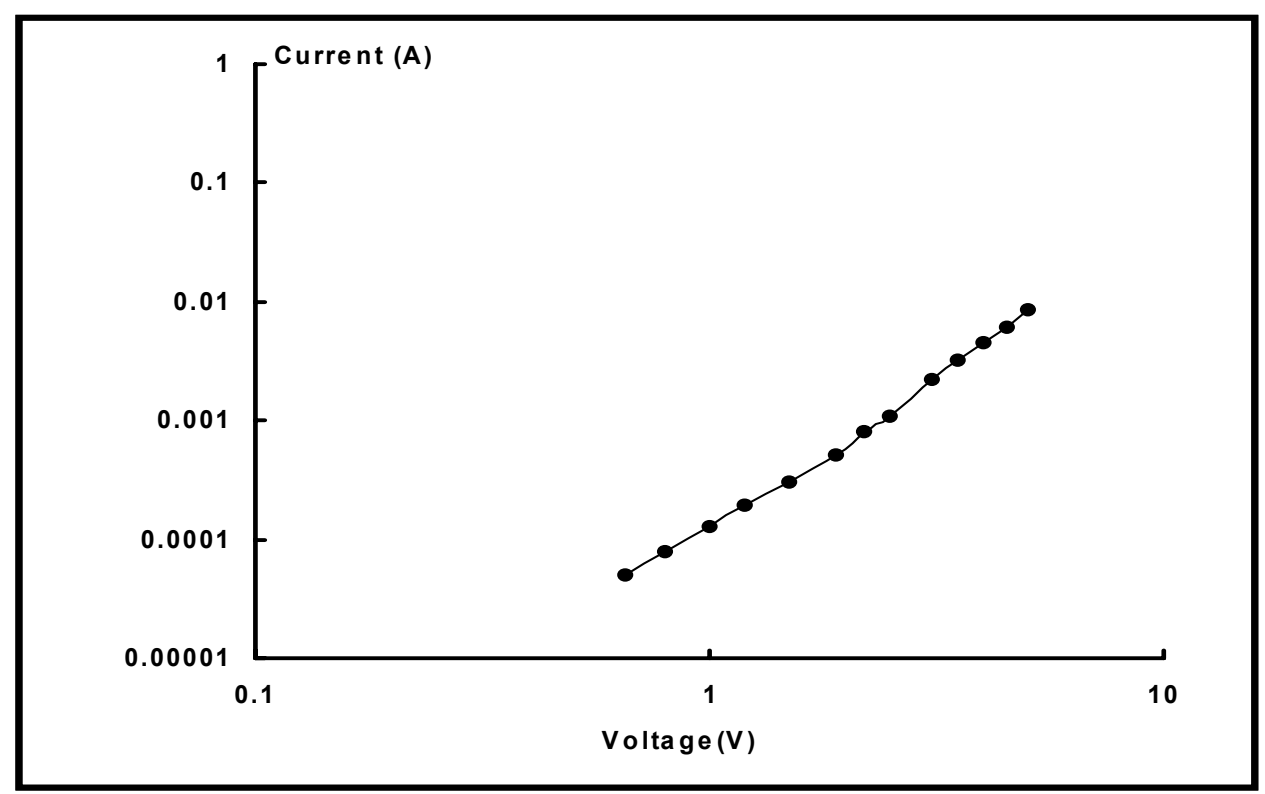

Fig. 7: Current-voltage characteristics of CdSe film in double logarithmic scale.

\section{CONCLUSION}

$\mathrm{CdSe}$ thin films prepared by (CBD) at different deposition temperatures (298, 318 and $328 \mathrm{~K})$. As the deposition temperature increased the band gap of prepared films increased also, this is due to increase in the deposition rate, and a decrease in grain size. The optical band gap decrease from 2 to $1.7 \mathrm{eV}$ after annealing. CdSe/p-Si device prepared by depositing $\mathrm{CdSe}$ film on $\mathrm{p}$-Si substrate, this shows a diode characteristic.

\section{REFERENCES}

Abass, A. K. ; Mohammad, M. T. (1986). Optical properties of fluorine-doped tin oxide films, J. Appl. Phys., 59 (5), 1641.

Chae, D. Y.; Seo, K. W.; Lee, S. S.; Yoon, S. H. ; Shim, I. W. (2006). CdSe thin films grown by MOCVD method using new single-source precursors.Bull. Korean Chem. Soc., 27 (5),762-764.

Elahi, M. ;Ghobadi N. (2008). Structural, optical and electrical properties of CdSe nanocrystalline films. Iranian physical J., 2 (1), 27-31.

Eya, D. D. O. (2006). Optical properties and applications of cadmium selenide (CdSe) thin films prepared by chemical bath deposition technique. The Pacific J. Sci. and Tech., 7 (1), 64-68.

Ezema, F.I. ; Osuji, R. U. (2007). Band gap shift and optical characterization of chemical bath deposition CdSSe thin films on annealing, Chalcogenide Letters, 4 (6), 69-75. 
Gudage, Y. G.; Deshpande, N.G.; Sharma, R. (2009). Influence of pH on microstructural and optical properties of electro synthesized CdSe thin films. J. Physics and Chem. of Solids. 70, 907-915.

Gudage, Y.G.; Deshpande, N.G.; Sagade, A. A.; Sharma, R.; Pawar, S. M.; Bhosale, C. H. (2007). Photoelectrochemical (PEC) studies on CdSe thin films electrodeposited from non-aqueous bath different substrate. Bull. Mater. Sci., 30 (4), 321-327.

Kale, R. B. ; Lokhande C. D. (2004). Influence of air annealing on the structural, optical and electrical properties of chemically deposited CdSenano-crystallites. Applied Surface Sci., 223, 343-351.

Kale, R.B.; Lokhande, C. D. (2005). Band gap shift, structural characterization and phase transformation of CdSe thin films from nanocrystalline cubic to nanorod hexagonal on air annealing. Semicond. Sci. Technol., 20, 1-9.

Khomane, A. S.; Hankare, P. P. (2009). Structural, optical and electrical characterization of chemically deposited CdSe thin films . J. Alloys Compounds, 9 (122), 1-4.

Lade, S. J; Uplane, M. D.; Lokhande, C. D. (2001). Photoelectrochemical properties of CdX (XDS, Se, Te) films electrodeposited from aqueous and non-aqueous baths. Materials Chemistry and Physics, 68, 36-41.

Masumdar, E. U.; Deshmukh, L. P. (2003). Photoelectrochemical properties of CdSe: Sb thin film based solar cells: influence of electrode thickness. Turk. J. Phys., 27, 271-278.

Moersch, G.; Rava, P.; Schwarz, F. ; Paccagnella, A. (1989). Thin-film transistors with sputtered CdSe as semiconductor. IEEE Transactions on Electron Devices,. 36(2), 449-451.

Murali, K. R.; Sivaramamoorthya, K.; Asath Bahadurb, S.; Kottaisamyc, M. (2008). "AC photoconductivity behavior of electron beam CdSe films". Chalcogenide Letters, $\mathbf{5}$ (11), $249-253$.

Pankove, J.I. (1971), "Optical processes in semiconductors" Dover Publ. Inc., New York.

Patel, K. D.; Jani, M. S.; Pathak, V. M.; Srivastava, R. (2009). Deposition of CdSe thin films by thermal evaporation and their structural and optical properties. Chalcogenide Letters. 6 (6), $279-286$.

Pawar, S. M.; Moholkar, A.V.; Rajpure, K. Y.; Bhosale, C. H. (2006). Electrosynthesis and characterization of CdSe thin films: optimization of preparative parameters photoelectrochemical technique. J. Physics and Chemistry, 67, 2386-2391.

Perez Gonzalez, A. M. ; Arreola, I. V. (2009). Effects of indium doping on the structural and optical properties of CdSe thin films deposited by chemical bath. Rev. Mex. FIS. , 55 (1), 51-54.

Sharma, K. S.; Kumar, L.; Kumar, S.; Sharma, T. P. (2008). Dependence of band gap on deposition parameters in CdSe sintered films. Chalcogenide Letters, 5, 73-78

Silverstein, R. M. ; Bassler, G. G., (1963). "Spectrometric identification of organic compounds" . Second edition John Wiley and Sons, New York, (USA).

Tamargo, M. C. (2002). " II-VI Semiconductor materail and theirapplication", Taylor and Francies, Newyork (USA). 